\title{
Grandparents Raising Grandchildren: Health Care Assistance ${ }^{1}$
}

\author{
Maisie Ross, Larry Forthun, Millie Ferrer-Chancy, and Angela Falcone ${ }^{2}$
}

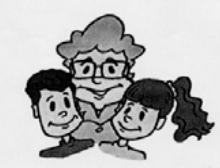

Goal: To provide information about health care assistance to grandfamilies who are residents in the state of Florida.

You have many options for health care coverage. These options include private insurance, Medicaid, Florida KidCare, and the Child Health Check-up Program. Private insurance is the most expensive option.

\section{MEdICAID}

Medicaid provides health care coverage to families or individuals with low incomes. You may apply for Medicaid insurance for the whole family or just for your grandchildren. Medicaid covers medical, mental health, and dental services. If your grandchildren qualify for Temporary Cash Assistance (TCA), Relative Caregiver Program, or Supplemental Security Income (SSI), they automatically qualify for Medicaid. However, you will still need to file an application for Medicaid coverage separately.

To learn more, or to apply for assistance, call Access Florida at 1-866-762-2237 or visit http://www.myflorida.com/accessflorida/.

\section{FLORIDA KIDCARE}

Florida KidCare has four different health programs for children.

1. KidCare Medicaid: This is a program for children from birth through age 18. To qualify, you must complete an application. Eligibility for this program is based on income.

2. MediKids: This is a program for children ages 1-4 who are not eligible for Medicaid. There is a $\$ 15-20$ monthly premium per child.

3. Florida Healthy Kids: This program provides an all-round health insurance plan for school-age children (ages 5-18). Most families pay a \$15-20 monthly premium per child. If you earn more than the maximum allowable income, you may purchase this coverage at the full price. This program does not enroll children throughout the year. You must enroll during an "open enrollment period."

4. Children's Medical Services Network (CMS Network): This is a health plan for children with special on-going health care needs. These include diabetes, leukemia, and behavioral health problems. It is for children under age 19 and provides medical services, supplies, therapies, and equipment. There is usually a $\$ 15-20$ monthly premium per child for this program.

For more information on Florida KidCare programs, call Florida KidCare at 1-888-540-5437 or visit http://floridakidcare.org.

\section{Child Health Check-up Program}

Grandchildren who qualify for Medicaid will also qualify for the Child Health Check-up Program. This program provides children with regular, comprehensive, health check-ups including comprehensive physical exams; nutritional and developmental assessments; vision, hearing and dental screenings; lab tests; immunizations; and health education guidance.

For more information on Child Health Check-ups, call your local health insurance provider, Medicaid office, or Access Florida at 1-866-762-2237.

1. This document, adapted from the December 2002 version of FCS2188, is FCS2188b, one of a series of the Department of Family, Youth and Community Sciences, Florida Cooperative Extension Service, Institute of Food and Agricultural Sciences (IFAS), University of Florida. Publication date: August 2009. Please visit the EDIS Web site at http://edis.ifas.ufl.edu.

2. Maisie Ross, Family and Consumer Sciences, West Palm Beach County Extension, 559 N. Military Trail, West Palm Beach, 33415; Larry F. Forthun, Ph.D., assistant professor, Department of Family, Youth and Community Sciences, Institute of Food and Agricultural Sciences, University of Florida, Gainesville, FL 32611; Millie Ferrer-Chancy, Ph.D., interim dean, Florida Cooperative Extension Service, University of Florida; and, Angela Falcone, former FYCS graduate student of University of Florida.

The Institute of Food and Agricultural Sciences (IFAS) is an Equal Opportunity Institution authorized to provide research, educational information, and other services only to individuals and institutions that function with non-discrimination with respect to race, creed, color, religion, age, disability, gender, sex, sexual orientation, marital status, national origin, political opinions or affiliations. U.S. Department of Agriculture, Cooperative Extension Service, University of Florida, IFAS, Florida A. \& M. University Cooperative Extension Program, and Boards of County Commissioners Cooperating. Millie Ferrer-Chancy, Interim Dean. 